Трофименко І.В., Бойко А.Д., Іваненко В.В., Федунов В.М.

\title{
АНАЛІЗ ФАКТОРІВ АВАРІЙНОСТІ СУДНОВОДІННЯ: ПРИЧИНИ І РЕКОМЕНДАЦІЇ ЩОДО ЇХ ПОПЕРЕДЖЕННЯ
}

Дослідження показали, щуо основною причиною морських аварій є людський фактор, поломки, пошкодження, відмова двигунів і суднового устаткування, а також прийняття неправильного рішення по управлінню судном. Тому для підвищення рівня безпеки руху суден відбувається зміни за рахунок ведення нових підходів і технологій управління судами.

У статті представлені результати аналізу зіткнень суден. В ході досліджень показано, які чинники впливають на безпеку судноводіння. В першу чергу розглянуті погодні умови, помилки при управлінні судном $i$ технічні несправності, які можуть привести до аварійності. Розглянуто найхарактернімі помилки $i$ порушення судноводїв, розкриті суб'єктивні і об'єктивні причини, дані обгрунтовані рекомендації для їх усунення.

Ключові слова: аварійність, безпека судноводіння, керування судном, фактори впливу

Вступ. На сучасному етапі безпека судноводіння морського транспорту є однією 3 серйозних проблем на сьогоднішній день [1]. Так за даними звітів Allianz Global Corporate \& Specialty (AGCS) світової флот втратив: за останні десять років в середньому 104 судна за рік i отримали щорічно ушкоджень більш ніж на 1000 морських транспортних засобів із загального числа світового флоту $[1,2]$ (см. Табл.1). У Табл.2 представлені інформація аварійних ситуацій і причини їх виникнення. Дослідження статистичних даних (див. Табл.2) [1] показали, що основною причиною морських аварій є людський фактор, поломки, пошкодження, відмова двигунів і суднового устаткування, а також прийняття неправильного рішення по управлінню судном. Тому для підвищення рівня безпеки руху суден відбувається зміни за рахунок ведення нових підходів і технологій управління судами (наприклад: Енавігація), впровадження сучасного навігаційного обладнання, автоматизації суднових процесів управління, а також вдосконалення інфраструктури портів i поліпшення їх операцій.

Аналіз літератури. 3 огляду на проведений аналіз літератури [2 $\div 5]$, можна констатувати, що на сьогоднішній день відбувається підвищення інтенсивність судноплавства. При цьому збільшується не тільки кількість судів, але і відбувається збільшення тоннажу i швидкостей судів, а також розвиток контейнерних i танкерних перевезень при скороченні стоянки часу судів. Все перераховане призвело до значного ускладнення умов судноплавної обстановки, особливо в акваторіях портів. Крім цього, в певний момент маневрування транспортних засобів в обмеженому водному просторі портових акваторіях в певних умовах може призвести до створення аварійних ситуацій.

Все це послужило приводом для того, щоб виробити заходи безпеки, що попереджають виникнення самого ризику зіткнень. У зв'язку з цим з 1972 року розроблені, а з 1977 року застосовуються Міжнародні Правила попередження зіткнень суден у морі (МППСС-72), в яких розкривається порядок судноводіння і маневрування в різних умовах видимості, в тому числі виконання типових маневрів розходження, обгону, зближення, перетину курсу, плавання в узкостях, оснащення судновим обладнанням для безпечного судноводіння i використання їх на судах [6]. Також Міжнародна морська організація (IMO) на сучасному етапі розробляє i застосовує норми і правила про заходи безпечного судноводіння i розведення шляхів. Значна увага при цьому приділяється розробці нових заходів: «жорстких» вимог і умов функціонування суднових систем і режимів судноводіння (що 
безпосередньо пов'язано з поліпшенням суднових технічних засобів). Так в сучасних умовах для розробки обгрунтованих заходів по боротьбі з аварійністю i, зокрема, із зіткненнями судів вже недостатньо одних посилань на хорошу морську практику [5]. Тому потрібен більш глибокий аналіз, що охоплює основні аспекти, що впливають на забезпечення безпеки судноводіння і стану аварійності ситуацій.

Говорячи про аналіз аварійних ситуацій як базі для вироблення заходів щодо зниження числа зіткнень, необхідно виявлення конкретних характерних помилок i порушень судноводіїв (не тільки фіксація порушень тих чи інших положень нормативних документів), а також встановлення причин помилок і порушень та ін.

Мета статті. Тому метою даної статті $€$ результати аналізу, які пов'язані 3 висвітленням ситуацій аварійності під час керування судном та факторів що впливають на якість безпеку судноводіння.

Таблиця 1

Кількість морських аварій і інцидентів в

залежності від ступеня тяжкості події

\begin{tabular}{|l|c|c|c|c|c|c|c|}
\hline $\begin{array}{c}\text { Морські аварії та } \\
\text { інциденти }\end{array}$ & 2014 & 2015 & 2016 & 2017 & 2018 & 2019 & Всього \\
\hline Дуже серйозні & 94 & 88 & 79 & 63 & 106 & 63 & 493 \\
\hline Серйозні & 880 & 706 & 832 & 799 & 849 & 752 & 4818 \\
\hline Менш серйозні & 1819 & 1902 & 1922 & 1842 & 1724 & 1919 & 11128 \\
\hline Інцидент & 451 & 645 & 411 & 559 & 585 & 328 & 2979 \\
\hline Всього & 3244 & 3341 & 3244 & 3263 & 3264 & 3062 & 19418 \\
\hline
\end{tabular}

Таблиця 2

Кількість аварійних ситуацій за факторами за 2019 рік

\begin{tabular}{|l|c|c|c|c|}
\hline \multicolumn{1}{|c|}{$\begin{array}{c}\text { Типи аварійних } \\
\text { ситуацій }\end{array}$} & \multirow{2}{*}{$\begin{array}{c}\text { Кількість } \\
\text { випадків }\end{array}$} & \multicolumn{3}{|c|}{ Категорії факторів, що впливають на тип аварій } \\
\cline { 3 - 5 } & 158 & 1 & $\begin{array}{c}\text { Ковнішні середа } \\
\text { судном }\end{array}$ & $\begin{array}{c}\text { Курування } 3 \\
\text { берегу }\end{array}$ \\
\hline $\begin{array}{l}\text { Небезпечна } \\
\text { ситуація }\end{array}$ & 2386 & 79 & 101 & 56 \\
\hline Людський фактор & 385 & 204 & 85 & 558 \\
\hline $\begin{array}{l}\text { Через стороннє } \\
\text { управління }\end{array}$ & 701 & 6 & 432 & 263 \\
\hline $\begin{array}{l}\text { Відмова суднових } \\
\text { систем або } \\
\text { обладнання }\end{array}$ & & & 5 & \\
\hline Невідома причина & 10 & 0 & 2372 & 978 \\
\hline Загальна кількість & 3640 & 290 & & \\
\hline
\end{tabular}

Виклад основного матеріалу. Більшість аварійних випадків відбувається з судами в портових водах, так як в умовах обмеженого простору плавання суднові навігаційні прилади не дає належну точність, ніж у відкритому морі. При цьому, швидко змінюється обстановка і підвищена напруженість роботи екіпажу (людський фактор), є ключовим в ході вироблення керуючого рішення щодо поточної обстановки [1]. При цьому, часом обсяг інформації, що надходить стає більше того обсягу, який може сприйняти і проаналізувати людина, внаслідок цього частина найважливіших відомостей залишається неврахованої. Чи не правильне прийняття рішення або так званий «людський фактор» може привести до водних пригод в внаслідок: неправильного маневрування, при розбіжності або обгоні, завищеній швидкості руху, несвоєчасного виявлення надмірного зближення, прорахунків при виборі безпечної дистанції та інші. Крім «людського фактора» необхідно враховувати фактори впливу на

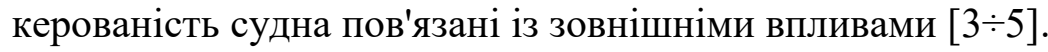


До зовнішніх факторів впливу на керованість судна відносять гідродинамічні сили, які змінюють рух і повороткість судна за рахунок конфігурації, конструктивних особливостей побудови судна і іiі надбудов. В основному до зовнішніх чинників відносять три взаємопов'язані сили: вітрове навантаження, хвилювання моря, тиску течії [7]. Таким чином, в результаті вплив зовнішніх сил необхідно враховувати особливості їх впливу на рух судна під їх впливом. Це дасть можливість оцінювати навігаційну обстановку i безпеку судноводіння. В результаті зовнішніх впливів поділяють сили на [7]:

інерційні - обумовлені інертністю судна і приєднаних мас води, і виникають тільки при наявності прискорень. Напрямок дії інерційних сил завжди протилежно до чинного прискоренню;

неінерціонние - обумовлені в'язкістю води i повітря i $\epsilon$ гідродинамічними i аеродинамічними силами.

Керованість судна під впливом зовнішніх факторів залежить від основних розмірів і якісних його характеристик, а також від їх співвідношень, тангажу, форми і розмірів палубних споруд і швидкості судна під впливом його опору і залежить від опору його руху, яке можна обчислити як $[3,7,8]$

$$
C=C_{t}+C_{f}+C_{w}+C_{k}+C_{a},
$$

де $C_{t}$ - опір тертя, викликане взаємодією корпусу судна і води з урахуванням тангажу;

$C_{f}$ - опір форми, викликане розподілом гідродинамічних тисків вздовж корпусу судна;

$C_{w}-$ хвильовий опір, яке визначається хвилеутворенням уздовж корпусу судна при його pyci;

$C_{k}$ - опір виступаючих частин корпусу судна, яке визначається наявністю керма, гвинта, виличні кілів і т. п.;

$C_{a}$ - аеродинамічний опір руху судна.

Дослідження літератури [3, 4, 7, 9] показало, що зовнішні фактори впливу на управління судном можна поділити на дві групи зовнішніх впливів: залежність від стану моря і гідрометеорологічних умов. У табл. 3 представлені результати аналізу гідрофізичних процесів впливу зовнішніх факторів на управління судном 3 урахуванням виділення основних елементів впливу.

Таблиця 3

Гідрофізичні процеси, які впливають на якість судноводіння

\begin{tabular}{|c|c|c|c|c|c|}
\hline $\begin{array}{c}\text { Гідро- } \\
\text { фізичні } \\
\text { процеси }\end{array}$ & $\begin{array}{c}\text { Навігаційні } \\
\text { пристрої }\end{array}$ & $\begin{array}{c}\text { Судові } \\
\text { енергетичн } \\
\text { і установки }\end{array}$ & Судно & $\begin{array}{c}\text { Людський } \\
\text { фактор }\end{array}$ & $\begin{array}{c}\text { Управлінське } \\
\text { рішення }\end{array}$ \\
\hline $\begin{array}{c}\text { Хвилюю- } \\
\text { ча } \\
\text { поверхня }\end{array}$ & $\begin{array}{c}\text { Переломленя, } \\
\text { затухання та } \\
\text { поглинання } \\
\text { сигналу }\end{array}$ & $\begin{array}{c}\text { Збільшення } \\
\text { енергетик- } \\
\text { чних втрат }\end{array}$ & $\begin{array}{c}\text { Фізико- } \\
\text { хіний вплив } \\
\text { на корпус } \\
\text { судна }\end{array}$ & $\begin{array}{c}\text { Психо- } \\
\text { неврологіч- } \\
\text { на хвороба } \\
\text { руху }\end{array}$ & $\begin{array}{c}\text { Вплив на } \\
\text { судно- } \\
\text { водіння }\end{array}$ \\
\hline $\begin{array}{c}\text { Гідромете } \\
\text { орологічн } \\
\text { і умови }\end{array}$ & $\begin{array}{c}\text { Вплив гідро- } \\
\text { метеорів на } \\
\text { якість прийман- } \\
\text { ня сигналу }\end{array}$ & $\begin{array}{c}\text { Вплив на } \\
\text { швидкість } \\
\text { судна }\end{array}$ & $\begin{array}{c}\text { Вплив вітру та } \\
\text { атмосферних } \\
\text { явиш на конят- } \\
\text { рукцію судно }\end{array}$ & $\begin{array}{c}\text { Вплив } \\
\text { атмосфер- } \\
\text { них явиш }\end{array}$ & $\begin{array}{c}\text { Вплив на } \\
\text { керованість } \\
\text { судна }\end{array}$ \\
\hline
\end{tabular}

Морська поверхня характеризується станом поверхневих хвиль (висоти і довжини хвилі) і її діапазоном, що утворює качку судна під дією гідродинамічних сил, обумовлених ефектом вітрового хвилювання, що обурюється. Це призводить до складності експлуатації гідромеханічних машин, механізмів і приладів через вплив виникають сил інерції, а також створює додаткові навантаження на міцні елементи корпусу судна і надає фізичний вплив на екіпаж $[1,4,8]$. При цьому основними елементами качки $є$ : амплітуда хитавиці (характеризує 
найбільше відхилення судна від початкового положення); розмах качки (характеризує суму двох послідовних амплітуд (нахил судна на обидва борти)); і період качки (час між двома послідовними нахиленнями або час, протягом якого судно здійснює повний цикл коливань, повертаючись до того стану, при якому почався відлік) [3, 9]. Наслідки хвилювання морської поверхні призводить до $[1,4,8]$ : зменшення швидкості ходу судна; збільшення витрати палива на одиницю шляху; зменшення точності розташування судна i визначення місцезнаходження морських об'єктів; утруднення обслуговування судна; додаткового навантаження на корпус судна; зміни умов управління судном; погіршення умов експлуатації суднових машин і механізмів; фізіологічного впливу на людей.

Хвилювання моря безумовно шкідливе явище вимагає додаткового вивчення для зменшення впливу на конструкції судна і його механізми, а також на екіпаж. Зазвичай для компенсації хвилювання морської поверхні на судах встановлюють виличні кили, активні керма, заспокійливі цистерни, гіроскопічні заспокоювачі, які в основному зменшують бортову качку [8].

Гідрометеорологічні умови впливають в основному на суднові навігаційні прилади, які використовуються при судноводінні. Найбільший вплив надають гідрометеори при прийомі радіосигналу в радіонавігаційних систем (РНС) і суднових радіолокаційних приладах РЛП, а також засобів автоматичної радіолокаційний прокладки (ЗАРП) у вигляді поглинання, спотворення сигналу, а також відображення його від морської поверхні [10]. Крім цього атмосфера також впливає на екіпаж судна у вигляді психоневрологічного впливу як в період виконання обов'язків, так і в період відпочинку. Також зовнішні чинники впливають на системи автоматики судна, енергетичні установки та автоматизацію судна цілому [11]. Це проявляється в погіршені експлуатаційних характеристик судна та параметрів технічних установок за якісними показниками. В даному випадку електроенергетичні системи є одним 3 найбільш складних комплексом суднових технічних засобів, що повинні забезпечувати безперебійне виробництво і розподіл електроенергії [9, 11]. Це пов'язано з якісним експлуатаційним періодом коли необхідно приймати управлінське рішення при швидкої зміні навколишнього оточення і режимів роботи агрегатів і механізмів, а також в умовах малого часу на виконання кожної операції. Тому від їх правильних дій значною мірою залежить живучість судна та безпека судноводіння.

Результати аналізу літератури можна уявити в табл. 4 у вигляді факторів впливів в період управління судном і необхідні дії для їх обліку і компенсації в якості рекомендацій щодо вивчення. На сьогодні багато питань пов'язані з урахуванням впливу зовнішніх впливів частково вирішені. Однак комплексного вирішення пов'язаної з взаємовпливом, не знайдено.

Для оцінки показника коефіцієнта ступеня ризику на основі всіх факторів впливу (об'єктивних і суб'єктивних) застосовується вираз (2) [7, 11]. При цьому, оцінка ризику кількісно характеризується відповідно, можливістю появи і рівнем «негаразди» збіг різних обставин. Таким чином, показник ступеня ризику (Р), буде визначаться декількома факторами, такими як

$$
P=K_{a}+K_{b}+K_{c}+K_{d}
$$

де $K_{a}$ - сумарні гідрометеорологічні чинники;

$K_{b}$ - тип судна, його мореплавство;

$K_{c}-$ технічний стан судна, його вік;

$K_{d}$ - людський фактор (досвід судноводія).

В даному випадку оцінка ризику представляє собою ймовірність того, що певна подія буде мати місце і воно буде мати потенційний негативний вплив в умовах судноводіння.

Таблиця 4 
Фактори, що впливають на судноводіння та напрямки

для врахування процесів впливу

\begin{tabular}{|c|c|c|}
\hline $\begin{array}{l}\text { № } \\
\text { 3/ח }\end{array}$ & $\begin{array}{l}\text { Фактори, що впливають } \\
\text { на якість судноводіння }\end{array}$ & $\begin{array}{c}\text { Напрямки щодо розробки рекомендацій } \\
\text { для врахування процесів впливу }\end{array}$ \\
\hline \multicolumn{3}{|c|}{ В умовах гідрометеорологічного впливу } \\
\hline 1. & Період часу року & \multirow[t]{2}{*}{ Вибір оптимальних режимів роботи суднових систем } \\
\hline 2. & Період доби & \\
\hline 3. & Biтep & \multirow{4}{*}{$\begin{array}{l}\text { Врахування впливу на площу судна для корегування } \\
\text { курсу в навігації }\end{array}$} \\
\hline 3.1. & Режим вітру & \\
\hline 3.2 . & Швидн & \\
\hline 3.3. & Напря & \\
\hline 4. & Тумани, дощі & \multirow{2}{*}{$\begin{array}{l}\text { Врахування в ближньому режимі роботи РНС, судової } \\
\text { РЛП та прокладки шляхів в ЗАРП }\end{array}$} \\
\hline 5. & $\begin{array}{l}\text { Атмосферний } \\
\text { температура писк, } \\
\text { води }\end{array}$ & \\
\hline 6. & Морська поверхня & \multirow{3}{*}{$\begin{array}{l}\text { Врахування в роботі судових РНС та РЛС (ЗАРП) } \\
\text { приймання сигналу }\end{array}$} \\
\hline 6.1 . & Хвилю & \\
\hline 6.2 . & Рівень & \\
\hline 6.3 . & Mopcs & Врахування в навігації судна \\
\hline \multicolumn{3}{|r|}{ Під час експлуатації судна } \\
\hline 1. & Напрямок руху & \multirow[t]{2}{*}{ Врахування помилок судноводіння } \\
\hline 2. & Навігаційні помилки & \\
\hline 3. & $\begin{array}{l}\text { Суднові } \quad \text { енергетичні } \\
\text { установки }\end{array}$ & $\begin{array}{lcccc}\text { Врахування вплив на } & \text { конструкцію } & \text { судна } & \text { та } \\
\text { енергетичні установки } & & & \\
\end{array}$ \\
\hline 4 & Маневрування судна & $\begin{array}{lcccc}\text { Врахування вплив } & \text { на конструкцію } & \text { судна } & \text { та } \\
\text { можливості енергетичних установок } & & \end{array}$ \\
\hline 5 & $\begin{array}{lr}\text { Робота } & \text { автоматизованих } \\
\text { систем } & \text { управління } \\
\text { судном, засоби, машини, } \\
\text { пристрої та вузли }\end{array}$ & $\begin{array}{l}\text { Врахування впливу на автоматизовані системи } \\
\text { управління судна та корегування роботи енергетичних } \\
\text { установок }\end{array}$ \\
\hline \multicolumn{3}{|c|}{ Помилки екіпажу під час судноводіння } \\
\hline 1. & Помилки бачення & Використання додаткових методів спостереження \\
\hline 2. & Психологічний вплив & Врахування при виконанні службових обов’язків \\
\hline 3. & Управлінські помилки & $\begin{array}{l}\text { Перерозподіл праці між людиною та машиною на } \\
\text { основі ергатичних систем управління судном }\end{array}$ \\
\hline
\end{tabular}

\section{ЛIТЕРАТУРА}

1. http://emsa.europa.eu/publications/reports/item/4266-annual-overview-of-marine-casualtiesand-incidents-2020.html.

2. https://www.agcs.allianz.com/news-and-insights/reports/shipping-safety.html

3. Бурмака И.А. Управление судами в ситуации опасного сближения / И.А Бурмака., Э.Н Пятаков., А.Ю. Булгаков - LAP LAMBERT Academic Publishing, - Саарбрюккен (Германия), $-2016 .-585$ с.

4. Вагущенко Л.Л. Расхождение с судами смещением на параллельную линию пути / Л.Л. Вагущенко. - Одесса: Фенікс, 2013. - 180 с.

5. Баранов Г.Л. Функціональна стійкість навігаційного обслуговування безпеки судноплавства на внутрішніх водних шляхах / Г.Л. Баранов, А.М. Носовський, I.В. Тихонов // Монографія - Київ: КДАВТ, 2012. - 149 с.

6. Convention on the International Regulations for preventing Collisions at sea (COLREG), 1972 (МППСС-72). 
7. Якушев А.О. Зависимость размеров судовой безопасной области от плотности распределения вероятностей позиционной погрешностей / А.О. Якушев [Текст] // Водный транспорт. - 2014. - №2 (20).- С. 84 - 88.

8. Пятаков Э.Н. Взаимодействие судов при расхождении для предупреждения столкновения / Э.Н. Пятаков, Р.Ю. Бужбецкий, И.А. Бурмака, А.Ю. Булгаков - Херсон: Гринь Д.С., 2015. - 312 с.

9. Носенко В.М. Судовые энергетические установки / В.М. Носенко. - Николаев: ФЛН Швед В.Д., 2013. - 443 с.

10. Современные информационные технологии обеспечения безопасности судноходства и их комплексное использование / В.Е. Леонов, В.И. Дмитриев, О.М. Безбах, А.А. Гуров, В.Б. Сыс, В.Ф. Ходаковский // под ред. Леонова В.Е. - Херсон: ИЦ ХГМА, 2014. - $324 \mathrm{c}$.

11. Вагущенко Л.Л. Бортовые автоматизированные системы контроля мореходности / Вагущенко Л.Л., Вагущенко А.Л., Заичко С.И - Одесса: Феникс, 2005. - 274 с.

\section{Трофименко І.В., Бойко А.Д., Іваненко В.В., Федунов В.М.} АНАЛИЗ ФАКТОРОВ АВАРИЙНОСТИ СУДОВОЖДЕНИЯ: ПРИЧИНЫ И РЕКОМЕНДАЦИИ ПО ИХ ПРЕДУПРЕЖДЕНИЮ

В статье представлены результаты анализа безопасности управления судном. В ходе исследований показано, какие факторы приводят к аварийности судовождения. В первую очередь рассмотрены погодные условия, условия наблюдения, ошибки при управлении судном и технические неисправности, которые могут привести к аварийности. Рассмотрень наиболее характерные ошибки и нарушения при управлении судном, а также раскрыты субъективные и объективные причины. На основе вышеизложенного представлены рекомендации по их предупреждению.

Ключевые слова: аварийность, безопасность судовождения, управления судном, факторы влияния

Trofimenko I.V., Boyko A.D., Ivanenko V.V., Fedunov V.M. ANALYSIS OF SHIPPING ACCIDENT FACTORS: CAUSES AND RECOMMENDATIONS FOR THEIR PREVENTION

The article presents the results of the safety analysis of ship control. Research has shown which factors lead to shipping accidents. First of all, weather conditions, ship handling errors and technical malfunctions, which can lead to accidents, are considered. The most characteristic errors and violations in the management of the vessel are considered, as well as subjective and objective reasons are revealed. Based on the above, recommendations for their prevention are presented.

Key words: accident, safety of navigation, ship control, factors of influence 